\title{
Present and Future Impact of Working/Non-Working Mothers on the Development of Political Orientations in Boys and Girls in Arkansas
}

\author{
Kenneth D. Bailey \\ Opinion Survey Research Corporation \\ Diane Kincaid Blair \\ University of Arkansas, Fayetteville
}

Abstract: Interviews with Arkansas schoolchildren regarding political awareness, perceptions, and trust indicate that there are some measurable differences between the children of employed and nonemployed mothers; that there are some pronounced differences which correlate to the mother's occupation; and that these differences are sometimes minimized, sometimes accentuated, according to the sex of the children involved. Our findings suggest that female influence in Arkansas politics, both directly through increased participation and indirectly through maternal transmission, may have more importance in the future than it has had to date.

This study deals with three contemporary currents which have been widely noted but rarely related to each other. the dramatically increasing number of "working mothers," i.e.. women who have children under 18 years of age and who are employed outside the home: the recent surge of studies exploring the many complex relationships between women and politics, with special emphasis on women as political participants; and the relatively recent recognition of the importance of mothers as agents of political socialization. Our study is aimed at exploring and illuminating possible relationships among these factors.

Our study attempts to answer four questions. First, are there measurable differences in the political awareness, political perceptions. and political interest between children of employed and nonemployed mothers? Second. does the kind of work done by the mother outside the 
home emerge as a significant factor in these comparisons? Third, is there a differential impact of the employment status of mothers on boy children as compared to the impact on girl children? Finally, what are the possible long-range implications of our findings on future political participation in Arkansas?

\section{Methodology}

To probe these questions, we analyzed cross-sectional data collected as the third "wave" of a multi-phase research project incorporating longitudinal, age-level, and cross-sectional research designs. ${ }^{2}$ Data analysis is based on approximately 3500 interviews (total $\mathrm{N}$ varies because of missing data) with elementary/secondary school children in several school districts in north and west Arkansas. Paper-and-pencil questionnaires were administered to children in the third, fifth, sixth, eighth, ninth, and eleventh grades. ${ }^{3}$ The questions reported on here were specifically designed to test political trust, interest, and knowledge-three factors with a proven relationship to political participation in adults.

Since the responses to our questions are primarily nominal and ordinal, we have selected the Chi-square test as a measure of significant differences among variables or among categories with a probability level of .05 . It should be noted that, generally, probability levels less than .001 are reported as .001 .

After a brief summary of the developments and data which prompted this study, we will report our findings, relate them to other recent studies, and suggest directions for additional research and analysis.

\section{Employed Mothers}

The number of employed women in Arkansas has been increasing dramatically in recent decades. As a percentage of the Arkansas labor force, women were 17 percent in 1940,30 percent in $1960,38.4$ percent in 1976. While this labor participation rate has been and remains somewhat less than that in the nation generally, women accounted for 88 percent of the increase in paid employment between 1960 and 1970 in Arkansas. ${ }^{4}$

Even more significant for this study are some marked shifts in the nature of the female labor force. Most women were once single and childless; most are now married and have children under 18 years of age. In fact by 1976 the labor participation rate of mothers with children under 18 was 49 percent, surpassing the 47 percent rate of all 
women over age 16, and standing in sharp contrast to the nine percent participation rate of mothers as recently as $1940 .^{5}$ Children of employed mothers were once an atypical group; now they are nearly the norm - the 28.2 million children of employed mothers in 1976 accounted for 46 percent of all children under age $18 .{ }^{6}$ Predictably, and conveniently for purposes of comparison, the school children in our sample divided almost evenly between those with employed mothers (50.5 percent) and those whose mothers played the traditional role at home (49.5 percent).

\section{Mothers as Political Actors and Agents of Socialization}

Moving from the reality of labor force statistics to the literature of political behavior and political socialization, the facts are not quite so incontrovertible. Nonetheless, there are broad areas of agreement within the particular parameters of this study.

With respect to women as voters, although for the first few decades after women's suffrage they were considerably less participatory than men, the over-all voting participation rates for men and women are now closely comparable. ${ }^{7}$ Even in Southern states like Arkansas, where differences persisted longest, men and women are now turning out in nearly identical numbers. ${ }^{8}$

While paid employment is by no means the exclusive or even predominant factor behind this diminishing differential (increasing education is clearly causative, ${ }^{9}$ as is gradual acceptance of the legitimacy - as distinct from the legality - of voting by women), ${ }^{10}$ there is general agreement that employment is positively related to political participation by women. For example, in 1968, 71 percent of all employed women voted while 63 percent of all women not in the labor force voted. ${ }^{\prime \prime}$

Whether owing to an increased sense of "stake,"12 additional political stimuli, ${ }^{13}$ or other employment-related factors, there is ample evidence that, in Lansing's succinct phrase, "When women move from the traditional homemaker role, as to go out of the house to take jobs, their voting rates increase.'

Turning from adult political behavior to early patterns of politicization, the noteworthy development for this study is a somewhat belated recognition that mothers are equal if not superior to fathers as agents of political socialization. The once-prevalent and largely intuitive father-dominant model has been supplanted by systematic demonstrations that mothers, especially if they are themselves 
politicized or have other advantages (e.g, greater education, employment, or ego strength), have the edge over fathers in transmitting political values and orientations. ${ }^{15}$ The advantage is usually ascribed to the greater affective ties between mothers and children than those between fathers and children ${ }^{16}$ and, because of same-sex modeling and girls' closer family ties, is particularly pronounced with daughters.

Given the general assumption that it is the high affect (physical proximity, emotional warmth) between mother and child which explains the maternal advantage in political socialization, some have suggested that when employed mothers become more like traditional fathers (i.e., part-time parents), the mother-child impact will decline. ${ }^{18}$ We think not, based on substantial documentation of the fact that employment outside the home does not necessarily lessen affective ties between mothers and their children. ${ }^{19}$ In fact, building upon concepts of behavior modeling, we would expect that more politicized mothers will eventually result in more politicized children, that is, children with more political knowledge and greater political interest.

Without extensive parental data- the political attitudes, activities, and partisan preferences of the parents of the children in this study - the extent of our explorations must necessarily be limited. Nevertheless, we are addressing a significant and generally neglected first step. What virtually all of these studies assume is that the mother's employment outside the home is a significant factor (albeit with variously predicted results), and it is this preliminary assumption, around which so many others revolve, which our data can begin to either substantiate, qualify, or question.

\section{The Data: Report and Analysis}

In answer to our first question-whether there are measurable differences between children of employed and nonemployed mothersthe immediate impression is that differences do indeed exist, but only on some of the political dimensions in question. 


\title{
Table 1 \\ Children's Trust and Confidence in Government, by Working/Nonworking Mothers (Positive Responses Only)
}

\begin{abstract}
Not
Work Work

Test of

Significance

${ }^{a}$ How much trust and confidence would you say you have in the people who run our government? . 5 54.2\% $55.4 \% \quad \mathrm{X}^{2}=0.465 \quad 1$ d.f.

${ }^{\mathrm{b}}$ How much of the time do (913) (937) $\quad \mathrm{p}=0.49$ you think you can trust the government in Washington to do what is right? .............44.5\% 44.0\% $\quad \mathrm{X}^{2}=0.074 \quad 1$ d.f. (757) (749) $\mathrm{p}=0.78$

${ }^{\text {a }}$ Responses were collapsed for positive and negative values. Possible responses were: Just about always, Most of the time, Some of the time, Not at all.

${ }^{\mathrm{b}}$ Responses were collapsed for positive and negative values. Possible responses were: A great deal, A fair amount, Not very much, None at all.
\end{abstract}




\section{Table 2 \\ Political Interest of Children, by Working/Nonworking Mothers}

c... How inter-

Not

Work
Test of

Work
Significance

ested are you in

current events

and what goes $19.3 \%(333) \quad 17.7 \%(304) \quad X^{2}=18.2842$ d.f.

on in the $\begin{array}{lll}59.2 & (1020) & 65.8\end{array}$

(1130) $\mathrm{p}=0.001$

government? ... 21.4

(369) 16.5

(283)

${ }^{\mathrm{d}}$ In general, how frequently would you say you talk about what's going on in the $57.9 \%(987) \quad 60.6 \%(1005) \mathrm{X}^{2}=4.279 \quad 1 \mathrm{~d} . \mathrm{f}$. government? ... 42.1 (717) $39.4 \quad$ (684) $p=0.326$

${ }^{\mathrm{c}}$ Possible answers were: Very interested, Somewhat interested, Not interested.

${ }^{d}$ Possible responses were: Frequently, Sometimes, Seldom, Almost never. Categories were collapsed into Frequently/Sometimes and Seldom/Almost never responses. 


\section{Table 3 \\ Political Awareness of Children, by Working/Nonworking Mothers}

Not

Work

${ }^{e}$ Who does the

$\begin{array}{cc}\text { Test of } \\ \text { Work } & \text { Significance }\end{array}$

most to make

laws for the

$55.5 \%(955)$

$61.0 \%(1050) X^{2}=10.5561$ d.f.

United States? . . 44.5

(766) $\quad 39.0$

(671) $\mathrm{p}=0.001^{\circ}$

Which. . decides

whether or not a

law follows the

rules of the $\quad 33.8 \%(573) \quad 37.8 \%(641) \quad X^{2}=5.882 \quad 1$ d.f.

country?.....666.2 (1124) $62.2 \quad$ (1054) $\mathrm{p}=0.015$

What branch. . .

of the government

does the presi- $\quad 40.9 \%(699) \quad 47.0 \%(805) \quad \mathrm{X}^{2}=12.4301 \mathrm{~d}$.f. dent represent?....59.1 (1009) $53.0 \quad$ (909) $\mathrm{p}=0.001$

${ }^{\mathrm{e}}$ Relevant responses were: Congress, Supreme Court, and Executive, respectively.

As Table 1 indicates, there is no significant difference between the two groups of children in terms of trust and confidence in government. Table 2 shows somewhat significant differences in the reported levels of political interest, primarily produced by the fact that children of nonemployed mothers more frequently state that they are "not interested." It is only with respect to the political awareness or knowledge dimension (Table 3 ) that a significant difference is evident: the children of employed mothers are consistently more knowledgeable. From this we might infer that the mothers who work outside the home are bringing something back into the home which correlates with slightly more politicized children. 
Table 4

Political Awareness of Children, by Nonemployed Mother/Type of Mother's Employment (Relevant Responses Only)

\begin{tabular}{|c|c|c|c|c|c|}
\hline & Nonemployed & Professional & White Collar & Blue Collar & $\begin{array}{c}\text { Test of } \\
\text { Significance }\end{array}$ \\
\hline $\begin{array}{l}\text { Who does the most to make } \\
\text { laws for the United States?.. }\end{array}$ & $55.5 \%(955)$ & $66.7 \%(254)$ & $63.0 \%(374)$ & $57.0 \%(416)$ & $\begin{array}{l}X^{2}=22.3913 \text { d.f. } \\
p=0.001\end{array}$ \\
\hline $\begin{array}{l}\text { Which. . decides whether or } \\
\text { not a law follows the rules of } \\
\text { the country?........... }\end{array}$ & $33.1 \%(573)$ & $44.3 \%(170)$ & $39.2 \%(233)$ & $31.4 \%(231)$ & $\begin{array}{l}X^{2}=25.9513 \text { d.f. } \\
p=0.001\end{array}$ \\
\hline $\begin{array}{l}\text { What branch. . of the } \\
\text { government does the presi } \\
\text { dent represent?.......... }\end{array}$ & $40.9 \%(699)$ & $57.7 \%(218)$ & $53.0 \%(314)$ & $36.6 \%(265)$ & $\begin{array}{l}X^{2}=70.535 \quad 3 \text { d.f. } \\
p=0.001\end{array}$ \\
\hline
\end{tabular}




\section{Table 5}

Children's Trust and Confidence in Government, by Nonemployed mother/

Type of Mother's Employment

(Positive Responses Only)

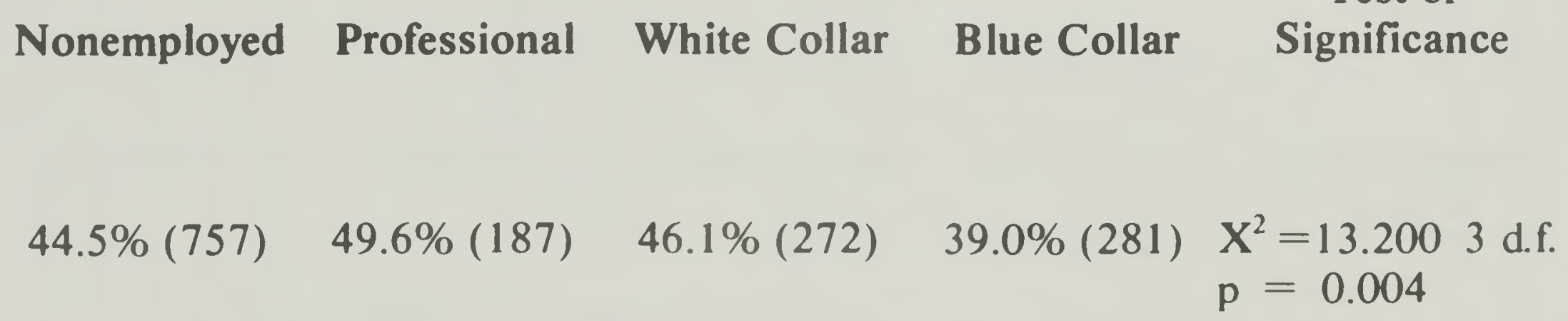

${ }^{\mathrm{c}}$ How much of the time do you think you can trust the government. . .to do what is right? ... 
Table 6

\section{Political Interest of Children, by Nonemployed Mother/Type of Mother's Employment}

\footnotetext{
Nonemployed Professional White Collar Blue Collar Significance

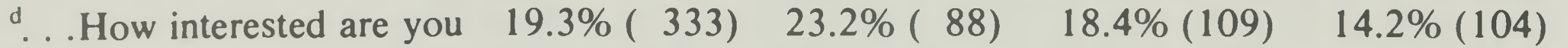

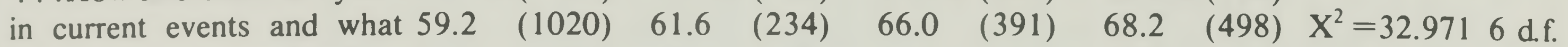
goes on in the government?... $21.4 \quad(369) \quad 15.3 \quad(58) \quad 15.5 \quad$ ( 192$) \quad 17.5 \quad$ (128) $X=0.001$ ${ }^{\mathrm{e}}$ In general, how frequently would you say you talk about what's going on in the
government? ............ $57.0 \%(974) \quad 65.3 \%(248) \quad 62.8 \%(371)$ government? .......... $43.0 \quad$ (734) $34.7 \quad$ (132) $37.2 \quad$ (220) $42.2 \quad$ (306) $p=0.005$

$57.8 \%(419) \quad \mathrm{X}^{2}=12.827 \quad 3$ d.f.

${ }^{a}$ Relevant responses: Congress, Supreme Court, Executive, respectively.

${ }^{b}$ Responses were collapsed for positive and negative values. Possible responses were: Just about always, Most of the time, Some of the time, Not at all.

${ }^{\mathrm{c}}$ Responses were collapsed for positive and negative values. Possible responses were: A great deal, A fair amount, Not very much, None at all.

${ }^{\mathrm{d}}$ Possible responses were: Very interested, Somewhat interested, Not interested.

${ }^{\mathrm{C}}$ Possible responses were: Frequently, Sometimes, Seldom, Almost never. Categories were collapsed into Frequently/ Sometimes and Seldom/Almost never responses.
} 
However, the answers to our second question-whether the type of work done by the mother also has significance-provide a somewhat different picture and underscore the dangers of aggregate analysis. When these children are further classified according to the mothers' occupational categories, significant differences emerge on all three political dimensions; however, the clustering of responses is not consistent. For example, on the awareness questions (Table 4), the children of professional and white-collar mothers group together as more informed than the children of blue-collar and nonemployed mothers, who also group together. The trust questions (Table 5) produce a descending sequence from most trusting children of professional mothers to the least trusting children of blue-collar mothers. On the political interest dimension (Table 6), a similar descendency emerges, though not so strongly, as does some clustering of the children of professional/white-collar mothers distinct from a clustering of children of blue-collar/nonemployed mothers.

What this seems to indicate is that the fact of maternal employment or nonemployment may not be so important as the specific type of work the mother is doing. There are more similarities than differences, for example, between the children whose mothers have blue-collar jobs and those who perform the traditional occupations of the household.

Much of this might reasonably be anticipated based on familiar patterns of the adult world, i.e., using the occupational category of the mother as a means of classification seems to produce the predictable class distinctions which emerge if family income or occupation of the head of household were employed as a variable. The only original insight here is the close comparability of the children of blue-collar and nonemployed mothers.

We asked, however, a third question-whether there is a differential impact of the employment status of mothers on boy children as compared to the impact on girl children. Once again, our answer is affirmative, and our findings at this third level of analysis raise questions about the totally explanatory power of the occupational category variable. 
Table 7

Political Awareness of Children, by Working/Nonworking Mothers,

Controlled for Sex of Respondent

(Relevant Responses Only)

\begin{tabular}{|c|c|c|c|c|c|c|c|}
\hline & & Not Work & Professional & White Collar & Blue Collar & Total by Sex & $\begin{array}{l}\text { Level of Sign. } \\
\text { Not Work/Type Work }\end{array}$ \\
\hline \multirow{2}{*}{$\begin{array}{l}\text { Who does the most to make } \\
\text { laws for the United States? }\end{array}$} & Male & $57.9(519)$ & $69.3(113)$ & $63.3(181)$ & $60.5(230)$ & $60.6(1063)$ & \multirow{2}{*}{ p. .02 } \\
\hline & Female & $53.2(436)$ & $64.3(119)$ & $62.9(193)$ & $.53 .6(186)$ & $56.3(934)$ & \\
\hline Level of Significance & & & & & & & p. .02 \\
\hline for Sex differences... & & p. .06 & p. .36 & p .98 & p. .06 & p. .04 & \\
\hline \multirow{2}{*}{$\begin{array}{l}\text { Which. . decides whether } \\
\text { or not a law follows the rules } \\
\text { of the country? }\end{array}$} & Male & $35.9(326)$ & $50.3(97)$ & $41.3(118)$ & $32.9(127)$ & $37.7(668)$ & \multirow{2}{*}{ p .0002 } \\
\hline & Female & $30.0(247)$ & $37.4(70)$ & $37.3(115)$ & $29.8(104)$ & $32.1(536)$ & \\
\hline $\begin{array}{l}\text { Level of Significance } \\
\text { for Sex differences... }\end{array}$ & & p. .01 & p. .02 & p. .37 & $p .41$ & p. .01 & $\mathrm{p} .03$ \\
\hline \multirow{2}{*}{$\begin{array}{l}\text { What branch or part of the } \\
\text { government does the president }\end{array}$} & Male & $42.6(380)$ & $62.5(120)$ & $53.2(151)$ & $39.6(151)$ & $45.9(802)$ & \multirow{2}{*}{ p. .00001} \\
\hline & Female & $39.0(318)$ & $52.4(97)$ & $52.8(162)$ & $33.1(114)$ & $41.8(691)$ & \\
\hline $\begin{array}{l}\text { Level of Significance } \\
\text { for Sex differences... }\end{array}$ & & p. .14 & p.06 & p. .99 & p. .08 & & \\
\hline
\end{tabular}




\section{Table 8 \\ Children's Trust and Confidence in Government, by Working/Nonworking Mothers, \\ Controlled for Sex of Respondent \\ (Positive Responses Only) ${ }^{\mathrm{a}}$}

\begin{tabular}{|c|c|c|c|c|c|c|c|}
\hline \multirow{3}{*}{$\begin{array}{l}\text { b How much of the time do } \\
\text { you think you can trust the } \\
\text { government in Washington to } \\
\text { do what is right? }\end{array}$} & & Not Work & Professional & White Collar & Blue Collar & Total by Sex & $\begin{array}{l}\text { Level of Sign. } \\
\text { Not Work/Type Work }\end{array}$ \\
\hline & Male & $42.6(377)$ & $54.5(103)$ & $44.2(125)$ & $35.6(134)$ & $42.7(739)$ & \multirow{2}{*}{ p. .0003} \\
\hline & Female & 46.4 (379) & $44.6(82)$ & $47.7(146)$ & $42.7(147)$ & $45.7(754)$ & \\
\hline $\begin{array}{l}\text { Level of Significance } \\
\text { for Sex differences... }\end{array}$ & & p. .13 & p .07 & p .44 & p .06 & p .17 & \\
\hline \multirow{2}{*}{$\begin{array}{l}{ }^{c} \text { How much trust and con- } \\
\text { fidence would you say you } \\
\text { have in the people who run } \\
\text { our government? }\end{array}$} & Male & $51.1(431)$ & $60.6(114)$ & $54.1(152)$ & $48.2(178)$ & $52.0(895)$ & \multirow{2}{*}{ p .04} \\
\hline & Female & $57.7(462)$ & $60.9(112)$ & $61.6(188)$ & $52.9(181)$ & $57.8(943)$ & \\
\hline $\begin{array}{l}\text { Level of Significance } \\
\text { for Sex differences. . }\end{array}$ & $\ldots \ldots$ & p. .008 & p .95 & p .08 & p. .24 & $p \quad .01$ & \\
\hline
\end{tabular}

- Responses were collapsed for positive and negative values.

b Possible responses were: Just about always. Most of the time. Some of the time. Not at all.

'Possible responses were: A great deal, A fair amount. Not very much. None at all. 
Table 9

Political Interest of Children, by Working/Nonworking Mothers,

Controlled for Sex of Respondent

How interested are

you in current events and what goes on in the Government?

$$
\begin{array}{ll}
\text { Female } & 17.4(143) \\
& 62.3(512) \\
& 20.3(167)
\end{array}
$$

Level of Significance

for Sex differences.

In general, how frequently

would you say you talk about

what's going on in the Gov't'?

$$
\begin{array}{ll}
\text { Female } & 57.9(344) \\
& 42.1(474)
\end{array}
$$

White Collar

$$
\begin{aligned}
& 20.1(57) \\
& 60.6(172) \\
& 19.4(55)
\end{aligned}
$$

$24.2(45)$

$61.3(114)$

$14.5(27)$

p. .53

$58.6(79)$

$41.4(112)$

$72.6(51)$

$27.4(135)$

p. .006
$16.9(52)$

$11.7(36)$

p .01

$61.1(110)$

$38.9(173)$

$64.5(109)$

35.5 (198)
$71.3(219)$

p. .45
Blue Collar

$17.0(65)$

$63.2(242)$

$19.8(76)$

$11.2(39)$

$73.8(256)$

$15.0(52)$

p .008

57.4 (163)

$42.6(220)$

$58.2(143)$

41.8 (199)
Total by Sex

20.1 (354)

$59.1(1039)$

20.7 (364)

$16.8(279)$

$66.2(1101)$

$17.0(282)$

p. .02

$57.5(741)$

42.4 (1005)

.53

$60.9(647)$

39.1 (1006)
Level of Sign.

Not Work/Type Work

p. .19

p. .00001

Level of Significance

for Sex differences.

p. 51

p. .90

p. .07 
For example, although our first impression was that the children of employed mothers do not differ from children of nonemployed mothers in terms of trust in government (Table 1), and our second impression was that there were significant differences between children grouped according to their mother's occupational status (Table 5), we now note that this class distinction is clearly evident among the boys but not statistically significant among the girls (Table 8). When it comes to expressed political interest, however, there is no class distinction among boys, but there are distinct variations among the groups of girls classified by their mothers' occupations (Table 9).

We did not intend to focus our study on sex differences per se, but these indications (that the mother's occupation was a significant variable in some cases for boys but in other cases for girls) strongly suggested that a further analysis by sex of children was warranted. Since the existence or nonexistence of sex-related differences has been extensively scruitinized, we can also place our findings in the context of existing research.

Beginning with the political awareness dimension (Table 7), the boys emerge as significantly more knowledgeable than the girls on each of the three information questions, and this pattern correlates closely with findings by others. Although the validity of some of the earlier studies reporting a sex-related difference in political knowledge has been challenged, ${ }^{20}$ most recent research has reported the same pattern of boys' being somewhat more informed. ${ }^{21}$

When our sample male and female children whose mothers have similar occupations are compared, two patterns emerge. First, in every single cell, on all three questions, the boys do have the knowledge edge. In only two instances, however, does the male/female difference reach the level of significance-indicating that class or, in this case, occupational similarity of the mothers does minimize the differences.

Interestingly enough, the only two significant differences emerge on what we would characterize as the most difficult of these general information questions, i.e., "Which of the following decides whether or not a law follows the rules of the country?" On this question, although boys with nonemployed mothers were not particularly knowledgeable, there was a significant male superiority compared with the girls with nonemployed mothers-an example of accentuated sex difference among the children with nonemployed mothers which emerges again in our study. 
The other cell in which a significant difference emerges-that comparing boys and girls whose mothers are professionals-has a lower level of statistical significance, but it is even more noteworthy. This is the only question in this study where the boys with professional working mothers showed any statistically significant superiority to the girls with professional working mothers, and that this difference should emerge on a question dealing with law and the courts tends to substantiate some earlier findings regarding strong sex differences with respect to the legal-judicial aspects of the political system. For example, Lare, Moore, and Wagner found that, among primary grade children, girls were twice as likely as boys to say that they did not know what a law is and three times as many girls responded "don't know" to the question "Why do we have laws?" - a very rare sex difference at that age. ${ }^{22}$

The fact that this difference persists even among the daughters of nonhousewife-mothers, indeed of mothers with professional occupations, points to the possibility of some direct or anticipatory modeling at work Professional women, in Arkansas even more than in the nation generally, are still overwhelmingly nurses and teachers. ${ }^{23}$ For daughters modeling on these mothers, the possibility of a personal future involvement with law and the courts might still be much less salient than it could be to their male counterparts, making it less necessary for the girls to focus on legal-judicial information.

The responses to our questions dealing with trust and confidence present an interesting pattern of no sex-related differences in trust of the "government in Washington (doing) what is right," but obvious sexrelated differences when talking about the "people who run our government" (Table 8). It is the exception in these reponses, however, that is of most interest. In every category except for those children from professional working-mother homes, the girls tend to be more trusting than do the boys. In reference to the first question, boys from professional working-mother homes trust the government considerably (but not significantly) more than do the girls (54.5 percent to 44.6 percent). And, although there is a very significant sex-related difference in reference to the people in government (p3.01), there is absolutely no difference between the sexes when controlled for professional working mothers (60.6 percent to 60.9 percent).

Most previous research regarding male/female comparisons on the trust dimension has concluded that girls have a more idealized 
conception of the government ( particularly of personal authority figures therein) and that girls-especially in the lower grades-are more trusting. On the other hand, Andrain, looking at fifth and eighth graders, concluded that girls are only slightly more deferential toward authority than boys but not to degrees of statistical significance, ${ }^{25}$ a pattern also reported by Orum et. al. ${ }^{26}$ Only Conway, Feldbaum, and Ahern have reported that fourth through sixth grade girls ranked somewhat higher than boys on a cynicism scale, ${ }^{27}$ and more recently Conway has reported, using sixth grade children alone, that there are no uniform sex-related patterns of confidence in government. ${ }^{28}$

Our student subjects were not, for the purposes of this study, separated by age or grade, so it is possible that a maturity factor that we did not detect is at work here. However, on the basis of our classifications, the mother's work status appears to have importance on this dimension as an explanatory variable.

When mothers are nonemployed, the sex difference that at least some others have found consistently appears: these girls are more likely than boys to project a "halo effect" 29 around governmental authority. When the children with professional mothers are compared, the sex difference no longer exists; children of blue-collar mothers break along the traditional sex lines only once, and children with white-collar mothers more frequently.

Our findings may help to explain the conflicting reports on this point in the literature. Those studies which found no sex differences might well have detected some if data had been further disaggregated by maternal occupation. Those sex differences which have been reported may indeed exist, but for somewhat different reasons than those usually suggested.

That the occupational status of the mother does have impact and that it impacts differentially on boy children than on girl children is especially indicated when we look at the political interest dimension (Table 9). Looking first at the question regarding expressed political interest, in every single mother-occupation cluster but one, we find a consistent pattern: boys are more likely than girls both to respond that they are "very interested" or that they are "not interested," while girls within these cells consistently group higher in the "somewhat interested" category. In the professional cluster, however, the pattern breaks: there are no statistically significant differences, although for once there is a slightly higher percentage of girls than of boys reporting 
that they are "very interested" and identical reportings of "somewhat interested."

On the second question, dealing with reported frequency of political discussions, the atypical tendencies of girls with professional mothers are even more apparent. They not only report a much higher frequency of political discussions than any of the other girls, but there is also a statistically significant superiority to the boys with professional mothers. We are reminded of the old nursery rhyme, "And when she was good, she was very, very good. .." What seems to emerge here is that, when the mothers not only work outside the home but work in advantageous occupations, their daughters not only overcome the traditional sex difference but reverse it.

Existing research on the political interest dimension has been somewhat contradictory. In general, however, although earlier studies reported, indeed emphasized, that boys were more interested in politics and government than were girls, ${ }^{30}$ only one recent study has noted this pattern. ${ }^{31}$ Most of the more recent research concludes that boys and girls are equally interested (or, more accurately, disinterested) in politics. $^{32}$

Our study would indicate that the reported death of the sex distinction on the political interest dimension has been somewhat premature but is prophetically accurate. The sex differences that we did find on this dimension, though statistically significant, are of modest magnitude. Furthermore, they seem to be primarily the product of the girls' greater tendency to say that they are "somewhat" rather than "very" or "not" interested, a tendency which may be illustrative of what has been described as the stronger and earlier female tendency to internalize the norms of "good citizenship."

On the other hand, we can certainly see the potential for the diminution of these differences. The girls whose mothers are not employed more frequently express "no interest" in politics and less political discussions than any of the other girls, whereas the girls whose mothers have professional jobs report equal political interest and even more political discussions than the boys in their mother-occupational category.

Do employed mothers have more highly politicized children in general and more highly politicized daughters in particular? Considering the clusterings of the children of nonemployed mothers with the children of blue-collar mothers, it would be simplistic to 
assume that the mere fact of maternal employment will produce more politicized children. However, the further facts that the children with professional mothers are more knowledgeable and interested and that the daughters of professional mothers usually compare equally or favorably with their male counterparts suggest a positive but more qualified hypothesis. If women increase not only their numbers but also their occupational status in the work force, their children will probably be more politicized, and the residual sex-related differences that are still evident on some political dimensions will continue to diminish or disappear.

\section{Caveats and Conclusions}

Our research indicates that there are some measurable differences on some political dimensions between the children of employed and nonemployed mothers, that there are some pronounced differences distinguishing children whose mothers do different kinds of work outside the home as well as in it, and that these differences are sometimes minimized, sometimes accentuated, according to the sex of the children involved.

We are mindful, however, that these observations are preliminary rather than conclusive.

First, it is possible that these differences are the products of factors for which we have no data (instructional methods, family income and education), or for which we have data (I.Q., urban-rural residence) but which were not employed in this particular study. It should also be noted that our subjects were white, and we would be extremely cautious about extending our generalizations to all children regardless of race since some research has indicated fewer sex differences among black children than among white children. ${ }^{34}$

Second, we are acutely aware that the mere fact that a mother is employed outside the home may mask countless additional variations. each with the potential of impacting on the political awareness, attitudes, or interest of her children. Since the more educated a woman is the more likely she is to work, are we seeing the results of employment or education? Considering the great variety of factors both drawing and forcing women into the contemporary labor force, the significant differences may be those that explain the woman's presence in the labor force rather than the effects of her being there. Is the mother working from choice or necessity? Does she enjoy or resent her work? Has her employment been generally beneficial or disruptive to the family? 
There are many other possibly relevant questions to which we do not have the answers. As Hoffman and Nye have cautioned, "The distance between an antecedent condition like maternal employment and a child characteristic is too great to be covered in a single leap." 35

It is also possible that our occupational categories are insufficiently sensitive to important distinctions within these broad groupings. As Flora has aptly observed, work can "liberate" women politically as well as personally, encouraging skills and habits of participation, or it can "simply add an alienating office or factory job to the already pressing labor required in the nuclear family." 36 For example, within the blue-collar category, the mother might have demanding responsibilities in a unionized plant and interact with a great many people who have considerable political interest or she might be doing menial, rote work in isolated and apolitical surroundings. Within the other occupational and nonemployed categories, an equally wide range of scenarios can be easily envisioned.

Perhaps the most important unknown in our study is other relevant family data. Although some of these mothers are single-parent breadwinners and homemakers, a factor which in itself could be significant, most of these employed mothers are part of a husband-wife earning and child-raising team, and most of the nonemployed mothers have husbands who are variously employed. What is the father's occupational category? Is it similar to or different from the mother's? Would the distinctions that we have noted hold firm, wash out entirely, or be substantially modified if the father's occupation were figured into the equation?

This, too, we intend to explore and report. At this point, however, we do think our data suggest that a very important variable - the mother's occupational status-may have been too often subsumed under the general category of family income or occupation of the chief wage-earner, and we hope additional research will pursue this possibility.

As for the possible long-range impact on future political participation in Arkansas, our predictions must be considered within the framework of national declines in voter participation generally. Factors far beyond the scope of this study (national scandals, media influence, mobility, alienation, etc.) will continue to set the broad parameters within which millions of Americans, including Arkansans, will choose whether or not to vote. 
Within that broad context, however, the specifics of this study point to a potentially more politicized state citizenry. As the numbers of working women in Arkansas continue to expand toward national averages, the small residual differential in female voting participation will probably continue to diminish and disappear. This trend will be accentuated as Arkansas women begin moving into the better paying and more prestigious occupations in numbers comparable to national norms. $^{37}$

Most important, our data indicate that the heightened politicization of employed women, particularly of women in advantageous occupations, tends to produce children, particularly daughters, who are somewhat more politically informed and politically interested than the children of mothers performing the traditional functions at home. In other words, female influence in Arkansas politics, both directly through increased participation and indirectly through maternal transmission, may well have considerably more importance in the future than it has had to date.

\section{Notes}

1. We use the familiar phrase "working mothers" only for introductory purposes, but henceforth will refer to "employed mothers" or "mothers working outside the home." We do this both for precision's sake and to avoid any implication that mothers who do not receive paychecks are therefore not working.

2. Kenneth D. Bailey, "The Development of Political Orientations in Children: A 'Telescoped' Longitudinal Approach," delivered at the 1977 Annual Meeting of the American Association for Public Opinion Researchers.

3. The fifth, eighth, and eleventh grades serve as the third panel of the longitudinal design, and the third, sixth. and ninth grades represent age-level (grade-across-time) data for previous (1973) and later(1976, 1977, 1978) interviews.

4. The Status of Women in Arkansas(Little Rock: Governor's Commission on the Status of Women, 1973), 1; Women in the Arkansas Labor Force 4(Little Rock: Research and Statistics Section, Arkansas Employment Security Division, January, 1978), 1. Nationally, women now constitute 40.5 percent of the civilian labor force.

5. Woman: 1977, The Status of American Women, International Women's Year Workshop Guidelines (Washington, D.C.: U.S. National Commission on the Observance of International Women's Year, 1977), 3.

6. Ibid., 9 .

7. In November, $1976,59.6$ percent of the national adult male population reported voting compared to 58.8 percent of the adult female population. U.S. Bureau of Census, "Voting and Registration in the 1976 Election." Current Population Reports, 4 P-20, No. 322.

8. For documentation and explanation of the sex difference in voting in the South, see Gerald Pomper. Voter's Choice 4(New York: Dodd, Mead \& Co., 1975), 69-76. By 1976, however, in the West South Central region (which includes Arkansas), the difference between male and female voting was less than 1 percent "Voting and Registration in the 1976 Election," 36.

9. Marjorie Lansing "The American Woman: Voter and Activist," Women in American Politics, ed Jane S. Jaquette (New York: John Wiley, 1974), 8-9.

10. John J. Stucker, "Women as Voters: Their Maturation as Political Persons in American Society," A Portrait of Marginality, ed., Marianne Githens and Jewel L. Prestage (New York David McKay, 1977), 271. 5.

11. Lansing, "The American Woman," 14-15.

12. Robert E. Lane, Political Life (Glencoe, Ill.: The Free Press, 1959), 218.

13. Lansing, "The American Woman," 19-20.

14. Ibid., 16.

15. M. Kent Jennings and Richard G. Niemi, The Political Character of Adolescence (Princeton. N.J. Princeton University Press, 1974), 153-178; Kenneth P. Langton and M. Kent Jennings, "Mothers versus Fathers in the Formation of Political Orientations," Kenneth P. Langton, Political Socialization (New York: Oxford University Press, 1969), 52-83. 
16. Langton and Jennings, "Mothers versus Fathers," 66-83: Jennings and Niemi, Political Character of Adolescence, 170.

17. Langton, Political Socialization, 168-9.

18. Jennings and Niemi, Political Character of Adolescence, 309.

19. Claire Etaugh, "Effects of Maternal Employment on Children: A Review of Recent Research," 20 Merrilt Palmer Quarterly (April, 1974) 71-75.

20. See for example Jean Grossholtz and Susan Borque, "Politics an Unnatural Practice: Political Science Looks at Female Participation," Politics and Society, 4:2 (Winter, 1974), 241-52: Lynne B. Iglitzin, "The Making of the Apolitical Woman: Femininity and Sex-Sterotyping in Girls," In Jane S. Jaquette, "Introduction," Jacquette, Women in Politics, 33-35.

21. Richard M. Merelman, Political Socialization and Educational Climates, A Study of Two School Districts (New York: Holt, Rinehart and Winston, 1971), 124-6; Jennings and Niemi, Political Character of Adolescence, 308; Charles F. Andrain, Children and Civic Awareness, A Study in Political Education (Columbus, Ohio: Charles E. Merrill, 1971), 137-8; Anthony M. Orum, Roberta S. Cohen, Sherri Grasmuck and Amy W. Orum, "Sex, Socialization and Politics," in Githens and Prestage, Portrait of Marginality, 2622. James Lare, Stanley W. Moore and Kenneth A. Wagner, "Images of Government: Their Evolution among Primary School Children," delivered at the 1977 Annual Meeting of the Southwest Political Science Association, 13-14. See also M. Margaret Conway, "Sex Differences in Children's Political Orientations: Continuity and Change," delivered at the 1976 Annual Meeting of the Southern Political Science Association, 8-9; Robert D. Hess and Judith V. Torney, The Development of Political Attitudes in Children (Chicago: Aldine, 1967), 178.

23. The Status of Women in Arkansas, 1.

24. Hess and Torney, Development of Political Attitudes, 179-1 84; Roberta S. Sigel and Marilyn Brookes, "Becoming Critical About Politics," The Politics of Future Citizens, ed. Richard G. Niemi (San Francisco: Jossey-Bass, 1974), 122-3.

25. Andrain, Children and Civic Awareness, 135.

26. Orum et al., "Sex, Socialization and Politics," 24-25.

27. M. Margaret Conway, Eleanor Feldbaum, and David Ahern, "Sex Differences in Children's Socialization to Political Regime Orientations," unpublished paper, University of Maryland, July, 1974, 6.

28. Conway, "Sex Differences in Children's Political Orientations," 6-7.

29. A phrase quoted by James A. Morris and Cal Clark, "Sex and Socio-Political Orientations of Honduran School Children," delivered at the 1975 Annual Meeting of the Southwest Political Science Association, 13. 30. David Easton and Jack Dennis, Children in the Political System(New York: McGraw Hill, 1969), 3378; Fred I. Greenstein, Children and Politics, rev. ed. (New Haven and London: Yale University Press, 1969), 115-18; Hess and Torney, Development of Political Attitudes, 186-90; Herbert H. Hyman, Political Socializatin, A Study in the Psychology of Political Behavior, rev. ed. (New York: The Free Press, 1969), 21-22.

31. Sigel and Brookes, "Becoming Critical," 123.

32. Andrain, Children and Civic Awareness, 130; Jennings and Niemi, Political Character of Adolescence, 305-6; Orum et al., "Sex, Socialization and Politics," $27-28$.

33. Hess and Torney, Development of Political Attitudes, 188; Merelman, Political Socialization and Educational Climates, 126.

34. Orum et al., "Sex, Socialization and Politics," 25, 27, 29.

35. Lois Wladis Hoffman and F. Ivan Nye, Working Mothers (San Francisco: Jossey-Bass, 1974), 128.

36. Cornelia Butler Flora, "Working-Class Women's Political Participation: Its Potential in Developed Countries," Githen and Prestage, Portrait of Marginality, 82.

37. In 1976, 21.5 percent of employed women nationwide were in professional, technical, or managerial strata; in Arkansas, only 17.9 percent of employed women were in these categories. Women in the Arkansas Labor Force, 15. 